\title{
Effects of apomorphine and haloperidol on exploratory behavior and latent learning in mice
}

\author{
SVEN AHLENIUS, JÖRGEN ENGEL, and MADELEINE ZÖLLER \\ Department of Pharmacology, University of Göteborg, Fack, S-400 33 Göteborg 33, Sweden
}

\begin{abstract}
In order to characterize the behavioral effects produced by drug-induced changes in central dopamine neurotransmission, the behavior of mice was studied in a maze. The animals were given haloperidol $(0.2 \mathrm{mg} / \mathrm{kg}$, IP), apomorphine $(0.1-3.2 \mathrm{mg} / \mathrm{kg}$, IP), or solvent vehicle, during a 30- and 10-min time of preexposure to the maze, respectively, and their exploratory activity was recorded. The ability of these animals to find food in the same maze was later $(+24 \mathrm{~h})$ compared with the performance of a group not previously exposed to the maze (naive). In comparison with naive animals, untreated mice preexposed to the maze displayed a more efficient performance (latent learning) when trained to find food in the maze. It was found that haloperidol $(0.2 \mathrm{mg} / \mathrm{kg})$ or apomorphine $(0.1-0.8 \mathrm{mg} / \mathrm{kg})$ significantly suppressed the exploratory behavior of the animals during the time of preexposure. However, animals thus treated learned the maze $24 \mathrm{~h}$ later as rapidly as animals treated with solvent vehicle. Higher doses of apomorphine (1.6-3.2 $\mathrm{mg} / \mathrm{kg}$ ) also produced a suppression of exploratory behavior similar to that seen after its administration at lower doses, or after treatment with haloperidol; however, these animals did not display latent learning $24 \mathrm{~h}$ later.
\end{abstract}

It is well known that animals learn to run for food in a maze at a faster rate if they have had previous experience in the environment. This phenomenon, generally described as latent learning (e.g., Mackintosh, 1974), may offer the possibility to dissociate the effects of a drug treatment on learning ability from its effects on performance. By treating an animal with a drug during preexposure to the maze, it is possible to study the consequence of the treatment on the ability of the animals to learn a maze at a later time (i.e., in a nondrug state).

In the present series of experiments, we used this procedure to further study the effects of drugs, known to interfere with central dopamine neurotransmission, on the behavior of mice. The animals were treated with the dopamine receptor blocking agent haloperidol or the dopamine receptor agonist apomorphine during preexposure to a maze, and the consequence of these treatments on maze problem solving for food in the nondrug state was investigated.

\section{METHODS}

\footnotetext{
Animals

Male NMRI mice (Anticimex, Stockholm) were used. They were kept under constant environmental conditions and an arti-

This work was supported by the Swedish Council for Social Science Research (380/76P) and the Swedish Medical Research Council (4247 and 4932). The illustrations were skillfully prepared by Mrs. Ingela Olsson and "A-V centralen" at the University of Göteborg. For generous gifts of drugs, we thank Leo, Helsingborg, and Sandoz, Basle.
}

ficial light-dark cycle (dark 1.00 p.m.-1.00 a.m) upon arrival from the breeder, and were allowed to adapt for at least 1 week in the laboratory before they were used in an experiment.

The animals were weighed at the time of the experiments and the mean weight on Day 1 was $24.5 \pm 3.0 \mathrm{~g}(\mathrm{n}=48)$ and $24.0 \pm 2.7 \mathrm{~g}(\mathrm{n}=48)$ on Day 2 (experiments shown in Figure 2). All experiments were performed between 2 and 6 p.m.

Drugs

The drugs used were: haloperidol (Haldol ${ }^{\oplus}$ Leo, Helsingborg) or apomorphine $\mathrm{HCl} \cdot 1 / 2 \mathrm{H}_{2} \mathrm{O}$ (Sandoz, Basle). Haloperidol was dissolved in a few drops of glacial acetic acid and the final volume was made up with $5.5 \%$ glucose. Apomorphine was dissolved in $0.9 \%$ saline with some ascorbic acid added. The solutions were freshly prepared and the drugs or the vehicle solvent were injected intraperitoneally in a volume of $20 \mathrm{ml} / \mathrm{kg}$ body weight.

\footnotetext{
Apparatus

A maze with the dimensions shown in Figure 1 was used. When the animals were allowed access to food, it was delivered by means of a manually operated "lock" in one of the open arms of the maze. The detailed training procedure is also described in Figure 1.

\section{Haloperidol Experiments}

On Day 1, some of the animals received haloperidol $(0.2 \mathrm{mg} / \mathrm{kg}$, IP) and $10 \mathrm{~min}$ later were placed in the maze. They were then allowed to explore the maze for $30 \mathrm{~min}$ (experienced group) with both doors of the start/goalbox retracted (i.e., no restraints were placed on their activity in the maze, and no food was available). The exploratory activity of the animals was assessed by counting the number of entries into any arm of the maze during the first and last 5-min time block of the experimental session. All animals, including a control group not placed in the maze on Day 1 (naive group), were starved for $18 \mathrm{~h}$ before the Day 1 experiments and given $1.5 \mathrm{~g} /$ mouse of dry food after the Day 1 experiments as the only food before the next experiment on the following day.
} 

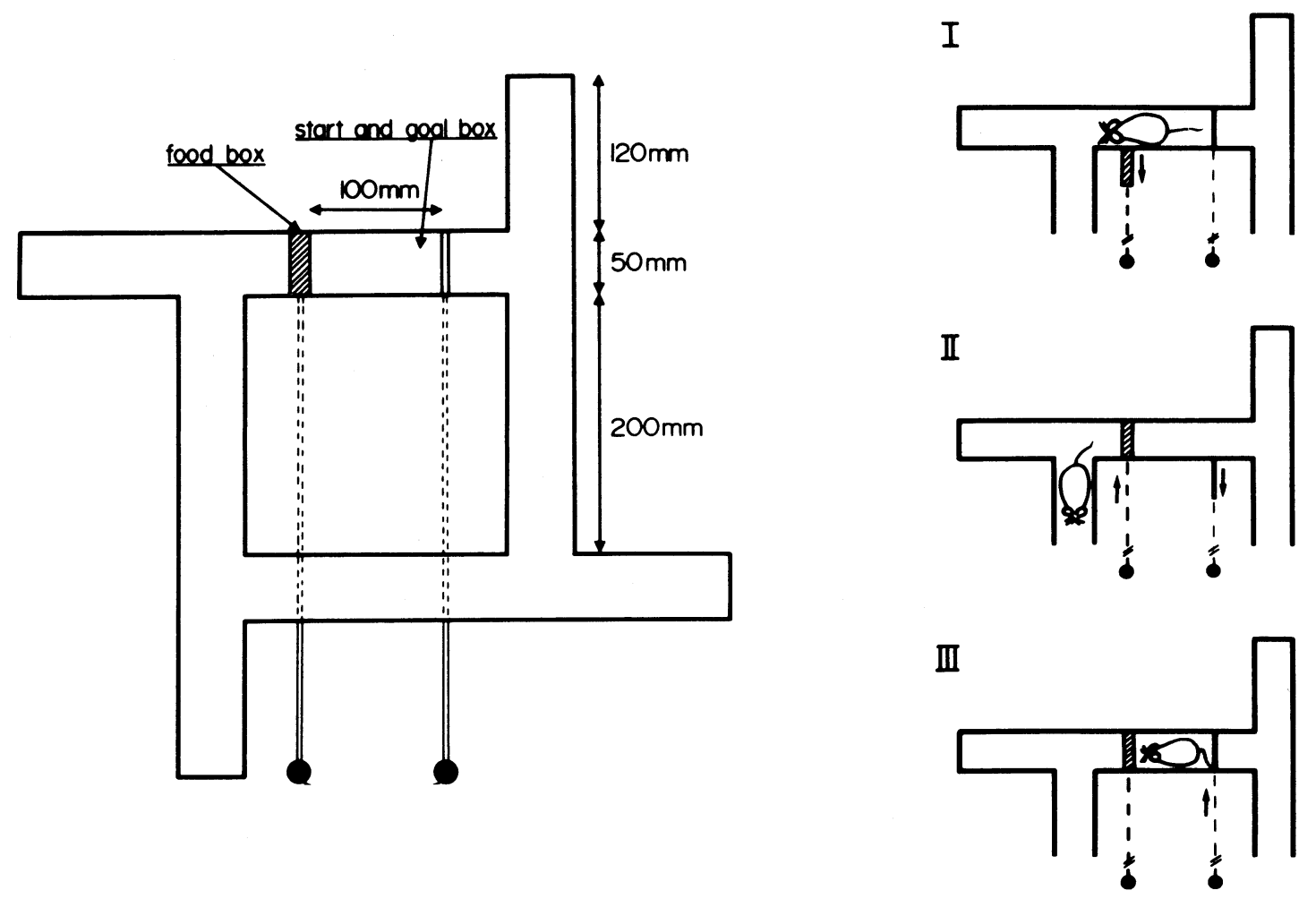

Figure 1. Maze learning in mice. The left part of the figure shows the dimensions of the maze, which is $50 \mathrm{~mm}$ high and made of black plastic. A transparent disk of Plexiglas is placed on top. The right part of the figure shows the procedure of a learning trial. The mouse has free access to food (available from the right side of the front door) for 20 sec between trials.

On Day 2, (24 $\mathrm{h}$ after the Day 1 experiments), all of the animals were allowed to obtain food in 10 trials, and the number of entries into blind alleys and retracking ("errors") in the maze, as well as time, were recorded during each trial. However, since preliminary experiments indicated less marked and more variable changes in time over trials, the number of entries was chosen as the dependent variable for presentation. Intertrial time, i.e., the time allowed free access to food, was $20 \mathrm{sec}$. After this time, the front door of the start/goalbox containing the food (cf. Figure 1) was withdrawn (irrespective of whether the animal in fact had eaten or not) and a new trial started.

\section{Apomorphine Experiments}

Since apomorphine has a shorter duration of action than haloperidol, we conducted pilot experiments to determine a shorter time of preexposure to the maze. It was found that untreated animals with 10,20 , or 40 min experience in the maze on Day 1 all displayed latent learning, i.e., fewer entries, when tested in two trials on Day $2(9.6,8.9$, and 8.0 entries, respectively) in comparison with naive controls $(16.1$ entries $[F(3 / 32)=5.69, p<.01]$ (cf. Figure 2). [Only two trials were run on Day 2, since, by comparing the Day 2 performance of experienced and naive animals in the haloperidol experiments, it became evident that the major differences between the two groups occurred within the first two trials, $t(46)=3.73, p<.001$ ) (cf. Figure 2).] Thus, the procedure in this experiment was simplified by exposing the animals for only 10 min (instead of 30) and by recording entries only during the first two trials on Day 2 . Finally, the number of entries on Day 2 were scored as on Day 1, i.e., an entry into any arm, irrespective of whether it was blind or not (or direction), was recorded. This appears to yield the same difference between Day 2 performance of naive and experienced untreated animals with 10 min of preexposure to the maze; naive animals make $168 \%$ of experienced controls when error entries are recorded (pilot experiment above), whereas the same figure is $170 \%$ of experienced controls when any entry is recorded (cf. Figure 6). Apomorphine $(0.1-3.2 \mathrm{mg} / \mathrm{kg}$, IP) was administered $5 \mathrm{~min}$ before the Day 1 experiments.

\section{Statistics}

Student's t test was used in experiments involving a comparison between two groups. In experiments with more than two groups, a one-way ANOVA was performed for overall significance and, if appropriate, followed by a t test based on the withingroup variance for comparison with a control (Davies, 1949).

\section{RESULTS}

\section{Haloperidol Experiments}

Vehicle control injected animals, with $30 \mathrm{~min}$ of preexposure to the maze on Day 1 , made fewer entries on Day 2 as compared to naive controls (Figure 2). The effect is statistically significant in 10 trials, with the total number of entries $33.5 \pm 14.3$ and $42.5 \pm 11.1$, respectively $[\mathrm{t}(45)=2.40, \mathrm{p}<.05]$.

Ten minutes after the injection of haloperidol, $0.2 \mathrm{mg} / \mathrm{kg}$, IP, or the $5.5 \%$ glucose vehicle, the animals were placed in the maze for 30 min on Day 1 . In animals treated with haloperidol, there was a 


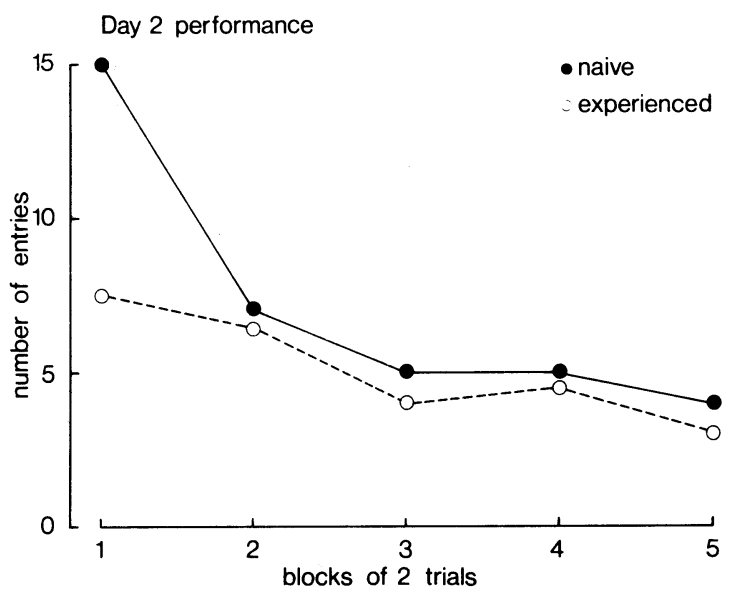

Figure 2. Effects of environmental preexposure on maze learning in mice. The figure shows the effect of $\mathbf{3 0} \mathbf{~ m i n}$ of preexposure to the maze on learning of the maze $24 \mathrm{~h}$ later, in comparison with the performance of a group of animals without experience to the maze (naive). For further details, see text.

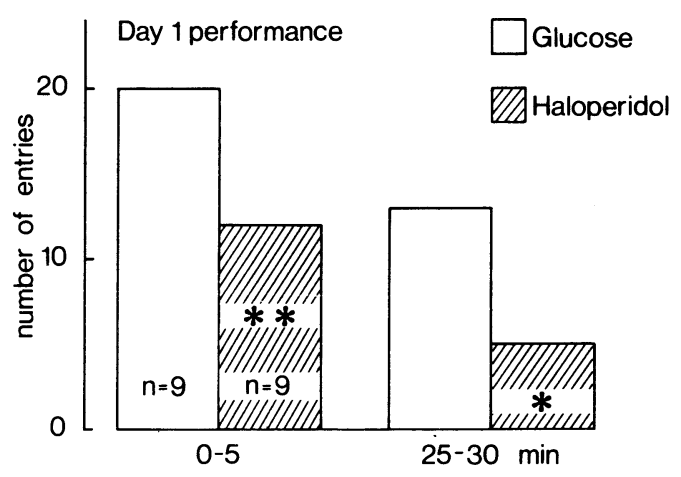

Figure 3. Effects of haloperidol on exploratory activity during preexposure to the maze. The figure shows the total number of entries into any arm of the maze during the first and last 5 min of a 30-min preexposure to the maze. Haloperidol, $0.2 \mathrm{mg} / \mathrm{kg}$, IP, or $5.5 \%$ glucose vehicle were given $10 \mathrm{~min}$ before the animals were placed in the maze. ${ }^{\star} p<.05 ;{ }^{\star \star} p<.01$ (Student's $t$ test).

marked and statistically significant decrease in exploratory activity during the first $5 \mathrm{~min}[\mathrm{t}(16)=3.28$, $\mathrm{p}<.01]$ and the last $5 \mathrm{~min}[\mathrm{t}(16)=2.81, \mathrm{p}<.05]$ of the $30 \mathrm{~min}$ in the maze, in comparison with glucose-treated controls (Figure 3). Both groups, however, seemed to habituate at the same rate.

When allowed 10 trials to obtain food on Day 2, there was no statistically significant difference in the performance of animals given haloperidol on Day 1 as compared to the performance of control animals given glucose. However, the number of entries of these two groups was less than that of naive controls, $F(2 / 24)=5.33, p<.025$ (Figure 4).

There were no statistically significant differences in the mean weight of animals treated with haloperidol as compared to animals given glucose on Day $1(23.8 \pm 1.9 \mathrm{~g}$ vs. $23.9 \pm 2.6 \mathrm{~g})$ or on Day 2 $(22.8 \pm 1.6 \mathrm{~g}$ vs. $23.3 \pm 2.2 \mathrm{~g})$.

\section{Apomorphine Experiments}

The animals injected with apomorphine 0.1$3.2 \mathrm{mg} / \mathrm{kg}$, IP, were placed in the maze for $10 \mathrm{~min}$ on Day 1, starting $5 \mathrm{~min}$ after the injection. During the first and last $3 \mathrm{~min}$ of the $10 \mathrm{~min}$ in the maze, there were statistically significant decreases in the exploratory activity of animals treated with apomorphine as compared to saline-treated controls on Day $1[\mathrm{~F}(6 / 108)=44.19, \mathrm{p}<.01$, and $\mathrm{F}(6 / 108)=$ $11.80, \mathrm{p}<.01$, respectively; (Figure 5). During the last $3 \mathrm{~min}$ of the $10 \mathrm{~min}$ in the maze, however, there were less marked effects by the lower doses $(0.1$ and $0.2 \mathrm{mg} / \mathrm{kg})$ of apomorphine. In fact, animals treated with $0.2 \mathrm{mg} / \mathrm{kg}$ of apomorphine

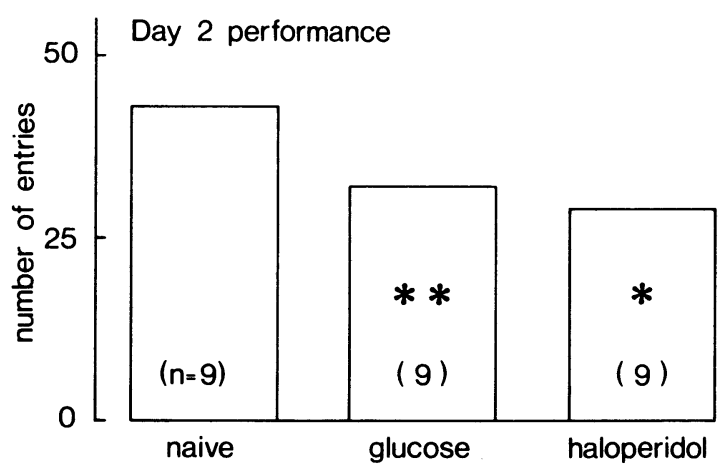

Figure 4. Effects of haloperidol on latent learning. The figure shows the number of entries made in 10 trials by animals with previous exposure to the maze and treated with $0.2 \mathrm{mg} / \mathrm{kg}$ of haloperidol or glucose on Day 1 and by animals without experience in the maze and treated with 5.5\% glucose (naive) on Day 1. "p < .05; **p < .01 (t test after one-way ANOVA, variance within groups: 65.77$)$.

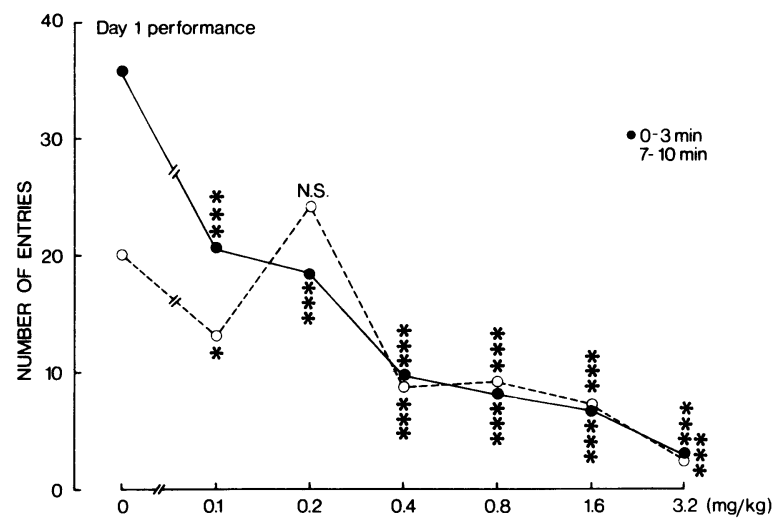

Figure 5. Effects of apomorphine on exploratory activity during preexposure to the maze. The figure shows the total number of entries into any arm of the maze during the first and last 3 min of a 10-min preexposure to the maze. Apomorphine, 0.1$3.2 \mathrm{mg} / \mathrm{kg}$, IP, or $0.9 \%$ saline vehicle were given $5 \mathrm{~min}$ before the animals were placed in the maze; $n=15$ for each dose of apomorphine, $n=25$ for vehicle control treated experienced and naive animals. N.S. $p>.05 ;{ }^{\star} p<.05 ;{ }^{\star \star \star} p<.001$ [t test after one-way ANOVA, $F(6 / 108)=44.19, p<.01$, variance within groups: $57.86(0-3 \mathrm{~min}) ; \mathrm{F}(6 / 108)=11.80, \mathrm{p}<.01$, variance within groups: 81.86 (7-10 min)]. 
displayed a higher, but not statistically significant, score on exploratory activity than did saline-treated controls. The effects of higher doses of apomorphine, $0.4-3.2 \mathrm{mg} / \mathrm{kg}$, during the last $3 \mathrm{~min}$ of observation were similar to the effects obtained by these doses during the first $3 \mathrm{~min}$.

In the maze learning experiments on Day 2, the saline-treated controls made $20.2 \pm 6.7$ entries $(10.2 \pm 6.4$ and $9.9 \pm 6.9$ in the two trials, respectively) as compared to $34.4 \pm 13.2$ entires (17.3 \pm 9.4 and $17.2 \pm 10.8$, respectively) in the naive controls $[\mathrm{t}(48)=4.82, \mathrm{p}<.001]$.

The effects produced by the administration of apomorphine on Day 1 in the doses of $0.1,0.2,0.4$, and $0.8 \mathrm{mg} / \mathrm{kg}$ on the Day 2 performance were all of the same magnitude and were not markedly different from the performance of the saline-treated controls (Figure 6). The administration of apomorphine in the doses of 1.6 or $3.2 \mathrm{mg} / \mathrm{kg}$ on Day 1 completely inhibited the display of latent learning when the animals were tested in the maze on Day 2.

There were no statistically significant weight differences among the various groups on Day 1 or on Day 2, and the mean weight of all animals $(\mathrm{n}=$ 132) was $25.2 \pm 2.9 \mathrm{~g}$ (Day 1) and $24.2 \pm 2.7 \mathrm{~g}$ (Day 2).

\section{DISCUSSION}

In the present experiments, maze learning was assessed by means of recording the number of entries into arms of the maze before the animals reached the goalbox; i.e., the lower number was taken as an indication of more efficient learning. In agreement with previous reports (see, e.g., Mackintosh, 1974) we found that preexposure facilitated learning of the maze.

Haloperidol, in a dose sufficient to significantly suppress performance on Day 1 , did not affect the learning ability of the animals. This is an indication of a specific suppression of behavior by the antipsychotic drug haloperidol, and these experiments provide additional support for the contention that antipsychotic drugs, which act by inhibiting central dopamine neurotransmission, have selective effects on behavior, i.e., they interfere with the ability to initiate a response but not with stimulus control by the environment (Ahlenius, 1973; Ahlenius \& Engel, 1975, 1976; Fibiger, Zis, \& Phillips, 1975). In line with this hypothesis is the present finding that haloperidol-treated animals habituated at about the same rate as glucose-treated controls.

Apomorphine, like haloperidol, produced a suppression of the exploratory activity in the maze on Day 1. A suppression of locomotor activity by low doses of apomorphine (maximal depression by about $0.2 \mathrm{mg} / \mathrm{kg}$ in mice) in activity cages has been

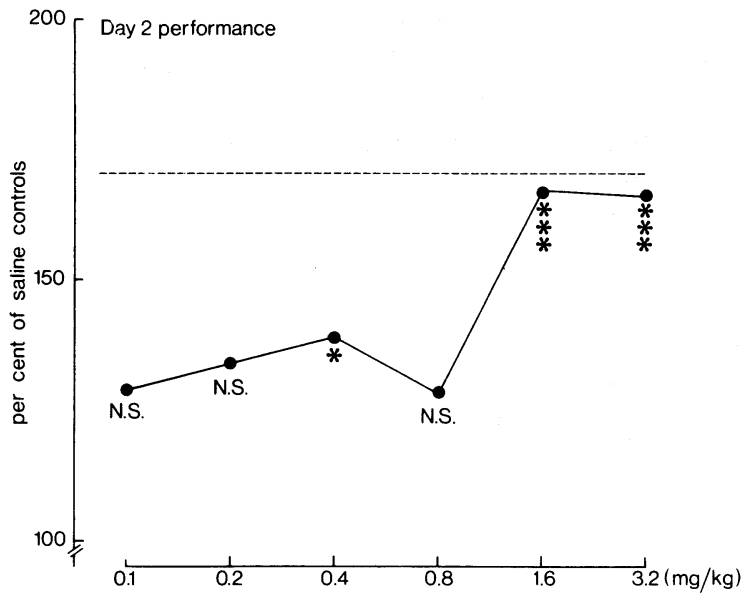

Figure 6. Effects of apomorphine on latent learning. The figure shows the number of entries made in two trials by animals with previous exposure to the maze and treated with apomorphine or saline (100\% in the figure) on Day 1 . The upper dotted line indicates the performance of naive saline controls. Statistical significance in comparison to Day 1 saline-treated controls indicated in the figure. N.S. $p>.05 ;{ }^{*} p<.05 ;{ }^{* \star} p<.001$ [t test after one-way $A N O V A, F(7 / 132)=4.17, p<.01$, variance within groups 124.88].

previously observed (Puech, Simon, Chermat, \& Boissier, 1974; Strömbom, 1976; Thornburg \& Moore, 1974). One explanation for this paradoxical effect of low doses of the dopamine-receptor agonist apomorphine is a preferential activation of postulated presynaptic dopamine receptors on the dopamine neurons (autoreceptors) with inhibitory functions (Carlsson, 1975). In the high-dose range, where a postsynaptic activation of the dopamine receptors by apomorphine in all probability predominates, a stimulation of motor activity is observed (in the mouse about $0.8 \mathrm{mg} / \mathrm{kg}$ and above) (cf. Puech et al., 1974; Strömbom, 1976; Thornburg \& Moore, 1974). This stimulation of motor activity is gradually characterized by uncoordinated movements and stereotyped behavior, such as sniffing, gnawing, and rapid movements of the head and forelegs. However, the recording of locomotor activity in the maze requires that the mice move into a new arm, and this may explain why no stimulation was observed after higher doses of apomorphine in the present experiments. In fact, in doses above $0.8 \mathrm{mg} / \mathrm{kg}$ of apomorphine, these animals usually got trapped in a blind alley, continuously sniffing and scratching the end wall.

Apomorphine in the dose range of $0.1-0.8 \mathrm{mg} / \mathrm{kg}$ had no marked effects on the learning ability of the animals, as assessed by recording the number of entries on Day 2. The slight, and not dose-dependent, attenuation observed is in all probability due to state-dependent effects of the drug (see Overton, Note 1). Thus, the suppression of exploratory activity, induced by these doses of apomorphine, 
which was of the same magnitude as that induced by haloperidol, did not interfere with the learning ability of the animals. Taken together, the present experiments show similar functional effects of low doses of the dopamine receptor agonist apomorphine and of the dopamine receptor antagonist haloperidol.

In doses above $0.8 \mathrm{mg} / \mathrm{kg}$, apomorphine in all probability interfered with the attention to and/or registration of changes in the environment, since animals thus treated did not differ in their learning ability from animals not preexposed to the maze. These effects may be due to an overactivation of central dopamine receptors. A loss of environmental stimulus control by an overactivation of central dopamine receptors has previously been shown in other behavioral situations (Ahlenius, 1974; Ahlenius \& Engel, 1976). Doses above $0.8 \mathrm{mg} / \mathrm{kg}$ of apomorphine in the mouse are generally known to markedly stimulate motor activity measured in activity cages, in all probability due to an activation of postsynaptic dopamine receptors (Puech et al., 1974; Strömbom, 1976; Thornburg \& Moore, 1974).

In conclusion, the present experiments show that although an impairment of central dopaminergic neurotransmission interferes with performance, it does not prevent an influence by the environment on later behavior of the animal. An overactivation of central dopamine receptors also produced a decrease in performance. In contrast, however, such an overactivation produced a loss of stimulus control in the maze as evidenced by a failure of the animals to display latent learning.

\section{REFERENCE NOTE}

1. Overton, D. A. Dissociated learning in drug states (state dependent learning). In D. H. Efron (Ed.), Psychopharmacology:
A review of progress 1957-1967. Washington, D.C: Public Health Service Publication No. 1836, 1968.

\section{REFERENCES}

Arlenrus, S. Inhibition of catecholamine synthesis and conditioned avoidance acquisition. Pharmacology, Biochemistry \& Behavior, 1973, 1, 347-350.

Ahlenius, S. Neurochemical control of behaviour: On the functional significance of drug-induced changes in central catecholamine receptor activation. Dissertation, Kungaelv: Gotab, 1974.

Ahlenius, S., \& Engel, J. Antagonism by haloperidol of the L-DOPA-induced disruption of a successive discrimination in the rat. Journal of Neural Transmission, 1975, 36, 43-49.

Ahlenius, S., \& ENGel, J. Normalization by antipsychotic drugs of biochemically induced abnormal behaviour in rats. Psychopharmacology, 1976, 49, 63-68.

Carlsson, A. Receptor-mediated control of dopamine metabolism. In E. Usdin \& W. E. Bunney, Jr. (Eds.), Pre- and postsynaptic receptors. New York: Marcel Dekker, 1975.

Davies, O. L. Statistical methods in science and production. London: Oliver \& Boyd, 1949.

Fibiger, H. C., Zis, A. P., \& Phillips, A. G. Haloperidolinduced disruption of conditioned avoidance responding: Attenuation by prior training or by anticholingergic drugs. European Journal of Pharmacology, 1975, 30, 309-314.

MaCkintosh, N. J. The psychology of animal learning. London: Academic Press, 1974.

Puech, A. J., Simon, P., Chermat, R., \& Boissier, J.-R. Profile neuropsychopharmacologique de l'apomorphine. Journal of Pharmacology (Paris), 1974, 5, 241-254.

Ströмвом, U. Catecholamine receptor agonists: Effects on motor activity and rate of tyrosine hydroxylation in mouse brain. Naunyn-Schmiedeberg's Archives of Pharmacology, 1976, 292, 167-176.

Thornburg, J. E., \& Moore, K. E. A comparison of effects of apomorphine and ET 495 on locomotor activity and circling behaviour in mice. Neuropharmacology, 1974, 13, 189-197.
(Received for publication September 28, 1976; revision accepted March 16, 1977.) 